\title{
Zarathustra's metaethics
}

\section{Neil Sinhababu}

To cite this article: Neil Sinhababu (2015) Zarathustra's metaethics, Canadian Journal of Philosophy, 45:3, 278-299, DOI: 10.1080/00455091.2015.1073576

To link to this article: http://dx.doi.org/10.1080/00455091.2015.1073576

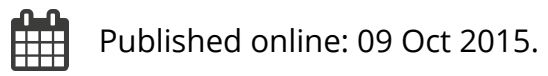

Submit your article to this journal $\pi$

Џ Article views: 50

Q View related articles $₫$

View Crossmark data $₫$ 


\title{
Zarathustra's metaethics
}

\author{
Neil Sinhababu* \\ Department of Philosophy, National University of Singapore, 3 Arts Link, Singapore \\ 117570, Singapore
}

(Received 29 October 2014; accepted 14 July 2015)

\begin{abstract}
Nietzsche takes moral judgments to be false beliefs, and encourages us to pursue subjective nonmoral value arising from our passions. His view that strong and unified passions make one virtuous is mathematically derivable from this subjectivism and a conceptual analysis of virtue, explaining his evaluations of character and the nature of the Overman.
\end{abstract}

Keywords: Nietzsche; Zarathustra; metaethics; virtue; subjectivism; Overman

Friedrich Nietzsche may be the most forceful critic of morality in all of philosophy. Yet he often ascribes value to actions, characters, and ways of life. How are these evaluative claims consistent with his rejection of morality? This paper argues that while Nietzsche regards moral judgments as false beliefs, he sees passions as making their objects subjectively valuable in a nonmoral way. His conception of virtue is mathematically derivable from this subjectivism and a conceptual analysis of virtue.

Part 1 argues that Nietzsche's favored values are subjective, nonmoral, and grounded in passion. Section 1.1 considers methodological questions about seeking metaethical views in Zarathustra, which contains the strongest textual evidence for subjectivism. ${ }^{1}$ Section 1.2 argues that Nietzsche is a moral error theorist. Section 1.3 presents the subjectivist interpretation of Nietzsche's own evaluative claims, showing how the features that make subjectivism a bad account of moral value make it a good account of Zarathustra's nonmoral values. Section 1.4 defends this subjectivist interpretation against Nadeem Hussain's fictionalist interpretation.

Part 2 presents the view of virtue that subjectivism favors, showing how it explains Nietzsche's evaluations of character. Section 2.1 derives the view that having strong and unified passions constitutes virtue from subjectivism and a traditional analysis of virtue. Section 2.2 uses this view of virtue to explain evaluations of character in Zarathustra, and Nietzsche's evaluations of Kant and Goethe. Section 2.3 offers an account of the Overman as having supremely

*Email: phins@nus.edu.sg 
strong and unified passions. Section 2.4 discusses Nietzsche's relation to Zarathustra.

\subsection{Zarathustra's metaethics?}

I'll first address methodological questions about the very idea of seeking metaethical views in Nietzsche, and especially in Zarathustra. Writing at the end of the nineteenth century, Nietzsche had no access to a hundred years of scholarship carefully marking out the metaethical terrain and presenting the advantages and disadvantages of the various positions. Is it, then, culpably anachronistic to apply our twenty-first century metaethical categories to him? And why should we seek his positive metaethical views in Zarathustra, of all places?

It's true that Nietzsche wasn't thinking about how to position himself optimally on anything like our current metaethical map. He didn't explicitly consider the relative advantages and disadvantages of fictionalism, noncognitivism, and subjectivism as positive views of value. If you went back in time, presented him with the contemporary metaethical menu, and asked him how we should understand his positive claims, he'd probably be surprised by the variety of options and take a long time to choose. He might reject some dogmas of contemporary metaethics, such as its purported independence from first-order normative questions.

So a good way to approach the question of Nietzsche's metaethics is to ask: what really mattered to him? Which metaethical views best match his assumptions and achieve his goals, with no extra points for solving problems that he didn't care about? The question of how we can value things after the death of God mattered tremendously to him, and that question is central to contemporary metaethics. Error theory best expresses his rejection of morality. Nietzsche's lack of concern for universality and objectivity and his emphasis on individual passion suggest that he really wants us to pursue a kind of subjective nonmoral value. His view that strong and unified passions make one virtuous follows from subjectivism.

Seeking metaethical views in Zarathustra may require a special defense. Hans-Georg Gadamer (1986) remarks that it is not even 'easy to disclose a conceptual content of this book,' expressing a sentiment common even among Nietzsche scholars. ${ }^{2}$ So it might seem strange to seek something so conceptually sophisticated as a metaethical view in Zarathustra. Further difficulties come from Zarathustra's fictional narrator and the seeming absence of its key ideas from Nietzsche's other works. How Nietzsche relates to Zarathustra is a perennial interpretive question, and many ideas in Zarathustra (like the Overman) aren't explicitly mentioned elsewhere. This can lead to a neglect of Zarathustra, perhaps rationalized by the thought that its ideas can't be so important if they're only expressed by a fictional character in poetry. ${ }^{3}$ 
Nietzsche saw Zarathustra as his best work and perhaps as the best thing ever. ${ }^{4} \mathrm{He}$ seems to have regarded Zarathustra as a superior version of himself, entitled to say things too great to express in his own voice. ${ }^{5}$ Paul Loeb (2005) suggests why only Zarathustra might present an idea, like the eternal recurrence: Nietzsche himself 'is not strong enough to affirm it. So instead he imagines what a philosopher would have to be like in order to affirm this thought and then constructs a narrative around him. For Nietzsche, this is a principled quarantine around the philosophical ideas he deems most important' (74). Section 2.4 describes how Zarathustra's passions make him a more wholehearted and convincing exponent of Nietzsche's greatest ideas.

The best way to show that it's worthwhile to seek metaethical views in Zarathustra is simply to reveal the clear statements of subjectivism in its poetry, as I'll do in Section 1.3. Many of these passages haven't been noted in interpretive debates. Attend to them, and Nietzsche's metaethical views become clear.

\subsection{Nietzsche's error theory about morality}

This section summarizes the evidence that Nietzsche is an error theorist about morality. Error theory combines cognitivism, the view that moral judgments are beliefs; with antirealism, the view that there are no moral facts. ${ }^{6}$ It treats all moral judgments as false beliefs. This rejection of morality raises the question of how Nietzsche thinks about value, a question that subjectivism answers.

The textual evidence supporting an error-theoretic interpretation spans many of Nietzsche's works, as Foenander (2011) convincingly argues. In Daybreak, Nietzsche writes, 'it is errors which, as the basis of all moral judgment, impel men to their moral actions' and 'I deny morality as I deny alchemy: but I do not deny that there have been alchemists who believed in these premises and acted in accordance with them - I also deny immorality: not that countless people feel themselves to be immoral, but that there is any true reason so to feel' (103). ${ }^{7} \mathrm{He}$ also treats moral belief as an 'enormous error' on par with regarding all objects as having genders ( $\left.\begin{array}{ll}D & 3\end{array}\right)$. He remarks that 'Popular medicine and popular morality belong together and ought not to be evaluated so differently as they still are: both are the most dangerous pseudosciences' (D 11). He suggests a 'new understanding of morality' on which suffering for morality's sake is 'founded on an error' (D 32). And he likens 'the moral significance of existence' to 'the music of the spheres,' saying that it likewise will soon be rejected as dream-beliefs are upon awakening $(D$ 100). Zarathustra says that 'There is an old illusion, which is called good and evil' ( $Z$ 'On Old and New Tablets' 9). In Beyond Good and Evil, Nietzsche rejects synthetic a priori judgments (which include moral judgments on Kant's view) as 'nothing but false judgments' $\left(B G E\right.$ 11). ${ }^{8}$ He later claims that 'There are no moral phenomena at all, but only a moral interpretation of phenomena' (BGE 108). 
Later, in Twilight of the Idols, he claims that 'there are altogether no moral facts. Moral judgments agree with religious ones in believing in realities which are no realities.' ('The Improvers of Mankind' 1). ${ }^{9}$ Describing all moral judgment as error and illusion and comparing morality to alchemy and religion, Nietzsche characterizes moral judgment as belief in a kind of thing that doesn't exist. Since error theory doesn't require any complicated semantics or metaphysics, such a reading isn't anachronistic. After all, Nietzsche's atheism makes him an error theorist about gods. He takes existing religious discourse to express belief in gods, believes that no gods exist, and thus takes religious belief to be false.

It's not uncontroversial to regard Nietzsche as an error theorist about existing moral discourse. Until recently, realist interpretations grounding morality in the will to power were more popular. ${ }^{10}$ These realist views present him as offering a radical new moral theory instead of rejecting morality altogether. While Nietzsche clearly has evaluative attitudes that he doesn't think are undermined by his objections to Christian morality, this gives little support to realist interpretations. Antirealist metaethical options including noncognitivism and fictionalism also accommodate moral claims. Other options like the subjectivism I'll suggest treat his evaluative discourse as nonmoral. The direct textual support for error theory and the availability of many antirealist options for accommodating Nietzsche's own evaluative claims weigh against realist interpretations. So I'll set realism aside, and argue for subjectivism against noncognitivism and fictionalism, which have prominent contemporary defenders.

\subsection{Subjectivism in Zarathustra}

This section argues that Nietzsche's own evaluative claims concern subjective nonmoral value that arises from our passions. This interpretation has become increasingly popular, though the evidence for it in Zarathustra has attracted little notice. ${ }^{11}$ I'll show how all the same features that make subjectivism an implausible account of moral value make it fit the nonmoral valuing discussed in Zarathustra quite well. Moral values are typically regarded as being universal, allowing for substantive disagreement, and providing a normative ethics that opposes acting on selfish or egotistical passions. While subjectivism is a poor theory of moral concepts because it doesn't fit these features of morality, it's a good theory about the nonmoral values articulated by Zarathustra, which differ from moral values in these respects, and more closely resemble aesthetic values or values of taste. Zarathustra also emphasizes the role of passion in making things valuable, as subjectivism requires.

I attribute this subjectivist view about value to Nietzsche:

Subjectivism: $\mathrm{x}$ is good for $\mathrm{Y}$ to the extent that $\mathrm{Y}$ desires $\mathrm{x}$, and $\mathrm{x}$ is bad for $\mathrm{Y}$ to the extent that $\mathrm{Y}$ is averse to $\mathrm{x}$. 
$\mathrm{Y}$ is a person or group of people, and $\mathrm{x}$ can be anything. I use 'to the extent that' rather 'if and only if' to indicate that $x$ 's value or disvalue varies on a continuous scale and is determined by the strength of Y's passions. ${ }^{12}$ The speaker need not share these passions to ascribe value. If Ariadne desires wine and I don't, I speak truly of Ariadne when I say that wine is good for her, rather than saying that wine isn't good. This is agent-subjectivism, not speaker-subjectivism. The goodness and badness isn't moral value. Accepting even subjective moral value would contradict error theory about morality.

'Passions' refers both desires and aversions. Desire and aversion generate different emotions. Desire causes delight when we get what we want and disappointment when we don't, while aversion causes relief when we get what we want and anxiety or dread when we don't. ${ }^{13}$ Desires to eat delicious food or to write a great novel give their objects value, while aversions like disgust at bad food or hatred of an enemy give their objects disvalue. I only address noninstrumental value and disvalue here, to avoid complexities about instrumental desires based on false beliefs.

Arthur Schopenhauer (1969) advances a similar subjectivism in The World as Will and Representation, which Nietzsche read enthusiastically at age 21:

We will now trace the meaning of the concept good ... This concept is essentially relative ... anything agreeable to the will in any one of its manifestations, and fulfilling the will's purpose, is thought of through the concept good ... in short, we call everything good that is just as we want it to be ... The concept of the opposite... is expressed by the word bad, more rarely and abstractly by the word evil, which therefore denotes everything that is not agreeable to the striving of the will in each case. $(360)^{14}$

He reiterates that 'every good is essentially relative; for it has its essential nature only in its relation to a desiring will' (362). While Nietzsche abandoned some Schopenhauerian views, there's no sign that he rejected this subjectivism. In light of Schopenhauer's views, subjectivism can't be regarded as anachronistic. As many other philosophers including Hume and Hobbes can be read as subjectivists even about moral value, the view that our passions confer a sort of nonmoral value on things isn't too outrageous to attribute to Nietzsche. ${ }^{15}$

Today, moral subjectivism is rightly regarded as implausible. Fundamental moral claims are typically seen as objective, being independent of agents' evaluative attitudes. The mere fact that someone morally values something doesn't imply that it has moral value for that person. Moral facts are supposed to be objective, so that wrong action is just wrong, rather than being wrong for us because of our passions. Just as we say that the earth is round rather than saying that the earth is round for each of us, we say that murder is wrong and not that murder is wrong for each of us. Talk of value for one person but not another is more natural in discourse about aesthetics and taste than in moral discourse. ${ }^{16}$ It's more plausible to regard the favored foods and music of others 
as good for them, even if we dislike them. Beauty is in the eye of the beholder, and de gustibus non disputandum.

Zarathustra's own values resemble aesthetics and taste more than morality in being agent-relative. In 'On The Spirit of Gravity,' Zarathustra describes his 'taste' in a variety of things. He says, 'He, however has discovered himself who says, 'this is my good and evil'; with that he has reduced to silence the mole and dwarf who say, 'Good for all, evil for all'.' At the end of the section, he says, 'This is my way; where is yours?' - thus I answered those who asked me 'the way.' For the way - that does not exist.' This is precisely how subjectivists reject universal good, evil, and ways. Zarathustra rejects even the weak 'phenomenal objectivity' that Poellner (2007) attributes to Nietzsche's positive values: 'What is objective in this sense is what is standardly presented as pertaining to the (everyday, phenomenal) object, just as the visible, phenomenal colour of a table appears as a property of the table itself ...' (233). Zarathustra's rejection of 'the way' in favor of what he explicitly calls 'my way' and 'my good and evil' differs starkly from how we perceive the color of a table as a property of the table itself, rather than as something essentially related to ourselves. While Poellner describes how we usually regard value, Zarathustra suggests a radical new option.

Zarathustra reinforces this message in 'The Last Supper,' where he suggests that the higher men assembled at his cave dine on lamb spiced with sage. When the voluntary beggar alone objects to this fancy meal, Zarathustra says, 'Be of good cheer ... as I am. Stick to your custom, my excellent friend, crush your grains, drink your water, praise your fare, as long as it makes you gay!' He accepts the subjectivity of his values, saying 'I am a law only for my kind, I am no law for all,' and describing people like him to whom his pronouncements are addressed. He explicitly likens his values to those of taste - they're fit for some, but not others, depending on what pleases them.

These discussions of value fit subjectivism better than noncognitivism. Both subjectivists and noncognitivists reject objective morality, but noncognitivists need not address their evaluative claims only to those like them, or say that things are only valuable for some and not for others. Noncognitivism about morality has the advantage of allowing us to criticize people whose evaluative attitudes lead them to entirely reject the criticism. Zarathustra's comments above suggest that his evaluative claims lack universality (truth about everyone) as well as objectivity (truth independent of anyone's attitudes toward it). The lack of universality is hard-wired into subjectivism, but not noncognitivism. 'On the Spirit of Gravity' and 'The Last Supper' suggest a metaethics hard-wired to exclude both universality and objectivity.

Noncognitivism and realism about morality have the advantage of allowing for kinds of disagreement that subjectivism doesn't. Noncognitivism allows us to disagree about morality by having opposed desires or emotions toward the same thing. ${ }^{17}$ Objective realism allows us to disagree about morality if our moral beliefs contradict each other. But on the subjectivism defended here, 
once we specify someone's passions and whether the thing fits those passions, there's no more room to argue about its value for that person. Furthermore, in requiring all value to be value for someone, subjectivism leaves no room for intelligent disagreement about whether something is valuable in a sense that is independent of any agent's attitudes toward it. We usually understand morality as permitting disagreements of this kind.

Zarathustra addresses disagreement in 'On Those Who Are Sublime': 'And you tell me, friends, that there is no disputing of taste and tasting? But all of life is a dispute over taste and tasting. Taste - that is at the same time weight and scales and weigher; and woe unto all the living that would live without disputes over weight and scales and weighers!' He accepts the role of our tastes in constituting value, much as Hume did, and shrugs at the objection that this view restricts the scope of intelligent disagreement. He points instead to the real conflict between individuals of opposed passions that plays out in 'all of life,' which concerns not only the things valued, but the people themselves. We shouldn't interpret his kind of value as permitting disagreements of the kind we see in ethics. It isn't something he cared about.

A moral subjectivism on which all passions give their objects value would entail a highly implausible normative ethics. Cruel or selfish desires don't make their objects morally valuable. Other metaethical views allow moral value to be independent of desires, or restrict the class of desires involved in moral valuing. Subjectivism, however, claims that the objects of all desires are good for us and the objects of all aversions are bad for us. It's implausible that desires for selfish gain or domination of others give their objects great moral worth.

While this is a problem for moral subjectivism, it supports interpreting Nietzsche as caring about subjective nonmoral value. He praises objects of strong desire more than things traditionally regarded as morally valuable. 'On the Three Evils,' where Zarathustra endeavors to 'place the three most evil things on the scales and weigh them humanly well' provides an example. ${ }^{18} \mathrm{He}$ evaluates sex, the lust to rule, and selfishness more positively than morality (especially in his time) allowed. If people desire these things, subjectivism will make them valuable for people. Of course, for those who don't desire these things or are averse to them, they'll lack value or have negative value. In 'On Chastity,' he recommends chastity only to those for whom it comes naturally, while saying that 'Those for whom chastity is difficult should be counseled against it.' Subjectivism allows us to understand Nietzsche's unconventional positive views - for people who desire sex, power, and selfish gain, they're valuable. He places less value on things that don't arouse such passion in us, even if they're usually regarded as more morally significant.

In 'On Enjoying and Suffering The Passions,' Zarathustra tells us how to 'speak and stammer' about goodness and virtue: 
'This is my good; this I love; it pleases me wholly; thus alone do $I$ want the good. I do not want it as divine law; I do not want it as human statute and need: it shall not be a signpost for me to overearths and paradises. It is an earthly virtue that I love: there is little prudence in it, and least of all the reason of all men. But this bird built its nest within me, therefore I love and caress it; now it dwells with me, sitting on its golden eggs.' Thus you shall stammer and praise your virtue.

In this lovely passage, the speaker wholeheartedly accepts the subjectivist claim that the good emerging from his passion is only his good, and not a good for all. He specifically rejects several other metaethical options, including a non-naturalist realism on which it would be 'divine law,' a more naturalistic view on which its scope would go beyond the individual by being 'human statute and need,' any view on which it emerges from 'prudence,' and any rationalist picture on which it results from 'the reason of all men.'

'On the Thousand and One Goals' describes how passionate valuing creates value. Zarathustra says that 'Good and evil have always been created by lovers and creators. The fire of love glows in the names of all the virtues, and the fire of wrath. Zarathustra saw many lands and many peoples. No greater power did Zarathustra find on earth than the works of the lovers: 'good' and 'evil' are their names.' Slightly earlier, Zarathustra explains that the creation of value depends on one's attitudes of valuing: 'To esteem is to create: hear this, you creators! Esteeming itself is of all esteemed things the most estimable treasure. Through esteeming alone there is value: and without esteeming, the nut of existence would be hollow.' He presents the existence of value as dependent on valuing itself, as subjectivism has it.

Zarathustra summarizes his combination of error theory and subjectivism in 'On The Thousand And One Goals': 'Verily, men gave themselves all their good and evil. Verily, they did not take it, they did not find it, nor did it come to them as a voice from heaven.' He reiterates this view concisely in 'On Self-Overcoming': 'good and evil that are not transitory, do not exist.' While objective values aren't transitory, subjective values are, lasting only as long as the passions that give rise to them.

\subsection{Hussain's fictionalist interpretation}

This section argues that a subjectivist interpretation of Nietzsche's positive values is superior to the fictionalist interpretation that Hussain (2007) presents in a celebrated recent paper. ${ }^{19}$ After discussing Hussain's fictionalist interpretation, I'll argue that all the textual evidence for it supports subjectivism as well. Subjectivism also better explains Nietzsche's first-order evaluative views and his greater emphasis on passion than pretense in value creation.

Hussain argues that Nietzsche wants his 'free spirits' to engage in 'a fictionalist simulacrum of valuing' (158). His view is that 'valuing, in Nietzsche's recommended practice, involves the generation of 'honest illusions.' It can be thought of as a form of make-believe, pretending, or in the non-Nietzschean 
phrase adopted here, 'regarding ... as': $\mathrm{S}$ values $\mathrm{X}$ by regarding $\mathrm{X}$ as valuable in itself while knowing that in fact $X$ is not valuable in itself' (166). The idea, then, is that free spirits are supposed to pretend or imagine that certain things as valuable in themselves, while knowing that these things are not in fact valuable. We agree that Nietzsche is an error theorist about morality while disagreeing about his positive values. Hussain thinks they arise through pretenselike attitudes in which we regard things as valuable in themselves. I think they're grounded in passions for the valuable things.

Hussain lays out an interpretive puzzle about how we should understand Nietzsche's positive conception of value. The four claims making up the puzzle are:

(1) A central task for Nietzsche's free spirits is the creation and revaluation of values;

(2) Nietzsche's free spirit 'conceives reality as it is';

(3) Nietzsche's nihilism: Nietzsche claims that nothing has value in itself and therefore all claims of the form ' $\mathrm{X}$ is valuable' are false;

(4) There is a close connection drawn in Nietzsche's works between art, the avoidance of practical nihilism, and the creation of new values. (158-164).

The puzzle really consists of (1), (2), and (3). (1) says that free spirits must engage in an activity that requires them to regard values as genuinely existing, after they create them or while they positively value them. Meanwhile, (2) and (3) together imply that the free spirits know that nothing has value. How can they interact with values as if they exist, satisfying (1), without violating the conjunction of (2) and (3) by falsely believing in them?

Hussain finds a solution in (4). Free spirits satisfy (1) by engaging in a 'fictionalist simulacrum of valuing.' Just as artists create fictional works that we can appreciate without regarding them as accurately representing reality, free spirits will create new values that we can appreciate without believing in them. Our attitude toward these new values, like the attitudes of readers toward novels, will be 'such that whether the content is false is no longer relevant' (179). Rather than acting on the basis of the values, we'll act while pretending the values are real, as children do in playing make-believe games.

While Hussain is right that Nietzsche comments favorably on how artistic representations honestly and innocently misdescribe reality, there's much less evidence that valuing involves pretense or imagination. The passages he cites from the preface of the Gay Science and section 107 praise being like artists, being content with appearance, and not letting the will to truth make our world unbearable, but don't explicitly invoke the distinctive mental states involved in a fictionalist simulacrum of valuing. ${ }^{20}$ GS 299, which discusses values of beauty and desirability, uses metaphors which can just as easily be interpreted to support a wide variety of anti objectivist views, including noncognitivism. ${ }^{21}$ 
There's a glimmer of what Hussain needs in $Z$ 'The Three Metamorphoses,' where the value-creating child is described as playing a game and likened to a creator, but mental states of pretense and imagination aren't mentioned. Motivational states are mentioned, however: 'the spirit now wills his own will.'

The significance of Nietzsche's praise of artists may simply be that we should accept some representations even though they don't fit the paradigms of objective truth. Artistic representations are like representations of subjective value in not presenting the world as it objectively is. But this isn't a good reason to reject them. Just as the will to truth shouldn't make us reject art, it shouldn't make us reject subjective value. As Nietzsche doesn't make much of pretense or imagination, this reading goes as far as we should go in pursuing the praise of artists as a guide to nonmoral valuing. It stops well short of fictionalism.

Subjectivism has a good solution to Hussain's puzzle. It allows agents to create values simply by having strong passions for things, satisfying (1). As long as they remember that the values they see are creations of their passions and don't mistake them for objective facts, they satisfy (2). And since subjective value doesn't consist in an intrinsic property of the valued object, they satisfy the part of (3) where Hussain writes that 'nothing has value in itself.'

Subjectivism, admittedly, doesn't satisfy the second half of (3): 'all claims of the form $\mathrm{X}$ is valuable are false,' which Hussain intends to exclude subjectivism. But the textual evidence for this part of (3) is weak. In two of the five passages (all of which are from Human, All-Too-Human) which Hussain cites in dismissing subjectivism, evaluative claims are taken not to be false but to involve 'injustice. ${ }^{22}$ Ascriptions of subjective value might be unjust in judging things on a basis other than their objective features. This fits 'injustice.' It would be injustice if a judge decided a case on the basis of his own desires rather than objective facts. Even worse, both $\mathrm{HH} 32$ and 33 address judgments about 'the value of life,' not about all value. Some problems discussed there about evaluating others' lives don't apply to evaluating music or food in light of one's passions, as subjectivism allows.

Nietzsche can easily accept subjective value while rejecting objective values like those of morality. ${ }^{23}$ Rejecting even subjective value claims would be surprising, as the existence of the things making these claims true is fairly uncontroversial. Clearly we have passions, and clearly the world sometimes includes the objects of our passions. The existence of subjective value follows from this. It's hard to see where Nietzsche denies that these sufficient conditions for subjective value obtain, or why he'd do so. The existence of passions and their objects, however, doesn't entail the existence of objective value.

Subjectivism explains Nietzsche's first-order evaluative view, while fictionalism can't. From subjectivism and agents' passions, one can derive what is valuable for them. What they desire has value for them, and what they're averse to has disvalue for them. As noted previously, subjectivism explains 
why Nietzsche's first-order evaluative views contradict traditional moral theories, ascribing value to selfish gain and dominating others. Fictionalism can't easily explain why Nietzsche is so committed to his distinctive and unusual first-order evaluative views. He could choose any pretense and drop it at will why stick to that one? Shaw (2007) notes that the problem deepens when we consider the necessity that Nietzsche ascribes to one's values (93). As pretenses, but not passions, can be arbitrarily adopted, subjectivism better explains Nietzsche's views both about the nature and necessity of value.

'On Enjoying and Suffering the Passions' provides the deepest criticism of the fictionalist interpretation. Rather than pretending things are valuable in themselves, the speaker has a clear-eyed awareness that value exists for him simply because of his passion. His passion is so strong that he can love its object even while having the subjectivity of its value at the forefront of his mind. One might think fictionalism would help here, allowing valuers to act within a pretense that their values really were objective. But part of the beauty of 'On Enjoying and Suffering the Passions' is that a sufficiently passionate valuer wouldn't need objectivity or even pretenses of it. The strength of passion is enough.

\subsection{Deriving a theory of virtue from subjectivism}

Having defended the subjectivist interpretation, I now turn to Nietzsche's conception of virtue. While metaethical questions have often been separated from first-order evaluative questions in the tradition following Moore, Nietzsche need not have seen metaethics as isolated in this way. In fact, a formula for virtue that emphasizes the strength and unity of one's passions follows mathematically from Nietzsche's subjectivism and a widely accepted account of how value and virtue relate. After deriving the formula, I'll use it to understand the evaluations of character that appear in Nietzsche's works.

This section presents the algebraic derivation of Nietzsche's conception of virtue, on which strong and unified passions make one more virtuous. Nietzsche surely never explicitly did the derivation or considered the formula that expresses this conception of virtue. But it explains how his subjectivism would lead him to think that strength and unity of passion is important for virtue, how he and other passionate creators regard themselves, and how he evaluates character.

Many philosophers take the virtue or vice of a passion to be grounded in whether its object is good or bad, and whether the passion favors or opposes it. To put it simply:

(V) Desires for good things and aversions to bad things are virtuous, while desires for bad things and aversions to good things are vicious.

Aristotle (1984) is an ancient representative of this view. ${ }^{24}$ Thomas Hurka (2001) is a recent one. ${ }^{25} \mathrm{~V}$ is highly intuitive, and plausibly a conceptual truth 
about how goodness and badness relate to vice and virtue. If this is right, it can be attributed to Nietzsche, as it's implicit in the concepts of value and virtue. While most philosophers who accept $\mathrm{V}$ are interested in moral virtue, I'll extend $\mathrm{V}$ to nonmoral virtue, as Nietzsche's subjective values are nonmoral ones.

Following V, here's a natural way to calculate someone's total virtue from the strengths of their passions and the values of their objects, summing over all objects:

$$
\Sigma(\mathrm{DG}+\mathrm{AB})-(\mathrm{DB}+\mathrm{AG})
$$

The first parentheses contain the two quantities contributing to virtue: to the extent that one desires something good or is averse to something bad, one's attitudes are virtuous. The second parentheses contain the two quantities diminishing virtue: to the extent that one desires something bad or is averse to something good, one's attitudes are vicious. DG, AB, DB, and AG multiply the strength of passion by the value of the object, following a multiplicative relation implicit in V. A negative number times a positive number is negative, while multiplying two negative numbers is positive. Likewise, negative attitudes toward positive value and positive attitudes toward negative value detract from virtue, while negative attitudes toward negative value contribute to virtue. The formula extends this multiplicative relation to quantify total virtue. The goodness and badness of the object are treated as separate here rather than aggregated, allowing something to be both good and bad at the same time instead of having these values neutralize each other. Desiring such an object involves a combination of virtue and vice. The net virtue of one's attitudes toward one thing consists in the virtuous products minus the vicious products concerning that thing. One's total virtue equals the sum of the net virtue of one's attitudes toward all things.

A subjectivism that grounds value in passion lets us substitute D for $G$ and A for $\mathrm{B}^{26}$ The value of something is determined by the strength and valence of someone's passions toward it, with desires creating value and aversions creating disvalue. This substitution gives us:

$$
\Sigma \mathrm{D}^{2}+\mathrm{A}^{2}-\mathrm{DA}-\mathrm{AD}
$$

Combining the last two terms produces the following formula for the total virtue of someone's character, summed over all objects:

Subjectivism on Virtue (SV): $\Sigma \mathrm{D}^{2}+\mathrm{A}^{2}-2 \mathrm{DA}$

As I'll now explain, SV emphasizes the importance of strong and unified passions. $^{27}$

The first part of the formula, $\mathrm{D}^{2}+\mathrm{A}^{2}$, which increases with the strength and focus of passion, explains why Nietzsche sees the Last Man as so poor in virtue. The Last Man's passions are weak, which makes him less virtuous according to $\mathrm{SV}$. His passions are also diffuse rather than being focused on any object. Since 
increasing desire generates linear increases in virtue when it's for something one doesn't already desire, but increases virtue quadratically when it's for something one already desires, having one's desires focus on one thing will more greatly increase one's virtue. (Having 3 desires of power 1 for different things scores $1^{2}+1^{2}+1^{2}=3$. Having 1 desire of power 3 scores $3^{2}=9$.)

The last term of the formula, $-2 \mathrm{DA}$, explains how another kind of disunity in passion reduces one's virtue. ${ }^{28}$ This disunity is exhibited by Christian ascetics who have both instinctual desire and acculturated aversion toward sex (or, perhaps, instinctual aversion and acculturated desire toward self-flagellation). Desiring something while being averse to it makes it both good and bad. Then one will be averse to something good and desire something bad, making one's passions vicious to some extent as well as virtuous. SV thus gives a score of 0 to those with no passions at all, and to those whose desires are all counterbalanced by equally strong aversions. ${ }^{29}$

Expressing Nietzsche's views mathematically is unusual, and one might wonder what it means to attribute this view of virtue to him. Nietzsche certainly never did this derivation or explicitly thought of SV. But the formula provides a good model of how he evaluated character, and I'd conjecture that its derivation models how his perspectives on virtue and value produced these evaluations. If $\mathrm{V}$ expresses how Nietzsche saw virtue, and if he saw the goodness and badness of things as subjectivism suggests, SV describes how his views combined. Just as one can see what one's beliefs entail without translating them into logical form, one can see a mathematical consequence of one's views simply by having those views and looking at the world. This is how Nietzsche came to see virtue as SV suggests.

For a concrete example of Nietzsche seeing virtue this way, think of him as he wrote Zarathustra. ${ }^{30}$ Following subjectivism, his great creative love for his book gave it tremendous value for him. And following V, his great creative love for something so valuable must have seemed to him to be the greatest thing about himself. ${ }^{31}$ Intense creative passion makes its object look wonderful, and constitutes oneself as a lover and creator of wonderful things. So one can see oneself as virtuous simply as the creator of something one loves. Aesthetic value is especially apt for a subjectivist treatment, and Nietzsche's own case shows how subjectivism and $\mathrm{V}$ combine to make artists' creative passions constitute their aesthetic virtue.

\subsection{Goethe vs. Kant and the 'pure perceivers'}

This section uses SV to understand Nietzsche's evaluations of character. Kant and Christian ascetics have disunified passions, which prevent them from having great virtue and make their passions vicious. Goethe has strong and unified passions, which makes him virtuous.

Zarathustra expresses the importance of unifying oneself in 'On Enjoying and Suffering The Passions': 
Once you suffered passions and called them evil. But now you have only your virtues left: they grew out of your passions. You commended your highest goal to the heart of these passions: then they became your virtues and passions you enjoyed.

And whether you came from the tribe of the choleric or of the voluptuous or of the fanatic or of the vengeful, in the end all your passions became virtues and all your devils, angels. Once you had wild dogs in your cellar, but in the end they turned into birds and lovely singers.

If suffering one's passions and calling them evil involves being averse to their objects, that makes those passions partly vicious. If one loses this aversion, the passions cease to be vices and become only virtues, as Zarathustra says.

Zarathustra disdains passions that disunify us by opposing our predominant passions. The 'pure perceivers' of 'On Immaculate Perception,' who proudly claim to appreciate the world in disinterested contemplation and without desire, provide such a model of vice to contrast the picture of virtue from 'On Enjoying and Suffering the Passions':

... you who are 'pure perceivers.' I call you - lechers.

You too love the earth and the earthly: I have seen through you; but there is shame in your love and bad conscience - you are like the moon. Your spirit has been persuaded to despise the earthly; but your entrails have not been persuaded, and they are what is strongest in you. And now your spirit is ashamed at having given in to your entrails, and, to hide from its shame, it sneaks on furtive and lying paths.

The 'pure perceivers' have disunified passions. They desire earthly things in their entrails (perhaps, their instincts) and are averse to the same earthly things in their spirits (perhaps, the parts of them that can be shaped by social and cultural forces, as these parts are susceptible to persuasion). Combining desire and aversion for the same thing, according to subjectivism, gives that thing both value and disvalue. As $\mathrm{V}$ suggests, this makes their passions partly vicious. In addition to being virtuous by desiring the good and being averse to the bad, they're vicious in desiring the bad and being averse to the good. This may be why Zarathustra calls them 'lechers' - the desires in their entrails are to some extent vices, because of the aversions in their spirit. ${ }^{32}$

More virtuous would be those whose spirits contained desires and not aversions for earthly things, in harmony with their entrails. The passionate valuers of 'On Enjoying and Suffering the Passions' become this way when they no longer see their passions as evil. They desire earthly things both in spirit and entrails, which combine to give the objects of their desires great value, making their desires highly virtuous. Nietzsche compares these two systems of passion in 'On Immaculate Perception.' Throughout the section, the moon is a metaphor for the pure perceivers. The end of the section includes an erotic 
description of dawn, when the moon is outshined as the sun's 'love for the earth approaches. All solar love is innocence and creative longing.' Nietzsche suggests that the virtue of those who desire earthly things with the entirety of their being outshines that of the pure perceivers as the sun outshines the moon.

The pure perceivers' aversions to what they instinctually desire are what Nietzsche criticizes in Kant, while the passionate valuers' harmony between spirit and entrails is what he admires in Goethe. As Leiter (1997) notes, Goethe is probably Nietzsche's favorite historical person. Nietzsche directly contrasts Kant and Goethe this way in three books. ${ }^{33} \mathrm{He}$ writes, 'How could one fail to feel how Kant's categorical imperative endangered life itself! ... this nihilist with his Christian dogmatic entrails considered pleasure an objection ... And this man was a contemporary of Goethe!' (The Antichrist 11). Of Goethe, meanwhile, Nietzsche writes 'What he wanted was totality, he fought the mutual extraneousness of reason, senses, feeling, and will (preached with the most abhorrent scholasticism by Kant, the antipode of Goethe); he disciplined himself to wholeness, he created himself' (TI 49). Nietzsche sees 'a fat worm of basic error' in Kant's view that the beautiful 'is what pleases without interest' (GM 3:6). ${ }^{34} \mathrm{He}$ prefers Stendhal's view that the beautiful is 'une promesse de bonheur,' defends the role of lust in aesthetic evaluation (GM 3:6), and appeals to this antiascetic aesthetics in praising Goethe's attitude toward sensuality $(G M 3: 2)$.

Nietzsche's views of Kant and Goethe are explained by an account of virtue that subjectivism would've led him to hold. This is further evidence of his subjectivism about value.

\subsection{The Overman}

This section presents an account of the Overman as having supremely strong and unified passions, achieved by turning the bad conscience against itself.

Zarathustra never provides a clear picture of the Overman's psychology. Much of what he tells us about the Overman is indirect, and emphasizes the strength of his passions versus the weakness of ours. The Overman is introduced with a discussion of the great contempt, in which one has contempt for one's happiness, reason, virtue, justice, and pity because they don't involve sufficiently strong passions ( $Z$ Prologue 3 ). One rejects one's happiness because it is 'poverty and filth and wretched contentment,' one's reason because it doesn't 'crave knowledge as the lion his food,' one's virtue because 'as yet it has not made me rage,' one's justice because one is not 'flames and fuel,' and one's pity because it 'is no crucifixion.' In all cases, the reason for contempt seems to be the weakness of one's passions. Since weak passions don't allow one to achieve great virtue, one must regard oneself with contempt.

Perhaps the best indication Zarathustra provides of the Overman's nature is the contrast with his opposite, the Last Man ( $Z$ Prologue 5). As previously 
discussed, the Last Man's distinctive feature is a lack of strong, focused passion that keeps $\mathrm{D}^{2}+\mathrm{A}^{2}$ small. He pursues only small pleasures and lacks any interest in striving for anything, because striving requires 'too much exertion.' If this is lacking virtue, having virtue would involve strong passions which make one strive for their objects, and fill one's world with value.

The clearest picture of the Overman emerges in the Genealogy. ${ }^{35}$ Much of the second essay discusses how guilt, or as Nietzsche calls it, the 'bad conscience,' arose in humans. Aggressive instincts that primitive humans weren't permitted to discharge against others were instead discharged inward, against oneself, and particularly against one's own instincts that would lead one to prohibited actions. As Nietzsche writes, 'hostility, cruelty, joy in persecuting, in attacking, in change, in destruction - all this turned against the possessors of such instincts: that is the origin of bad conscience' (GM II:16). Someone whose instincts were divided against themselves in this way would have disunified passions that detract from virtue according to SV. At the end, he writes:

\begin{abstract}
Man has all too long had an evil eye for his natural inclinations, so that they have finally become inseparable from his 'bad conscience.' An attempt at the reverse would in itself be possible - but who is strong enough for it? - that is, to wed the bad conscience to all the unnatural inclinations, all those aspirations to the beyond, to that which runs counter to sense, instinct, nature, animal, in short all ideals hitherto, which are one and all hostile to life and ideals that slander the world. (GM II:24)
\end{abstract}

Nietzsche describes the person whose bad conscience focuses only on his unnatural inclinations like Zarathustra describes the Overman - 'the redeeming man of great love and contempt ... this bell-stroke of noon and of the great decision that liberates the will again and restores its goal to earth and its hope to man. ${ }^{36} \mathrm{He}$ then silences himself, saying that speaking about this is something for which 'only Zarathustra has a right' (GM II:25).

The way the end of the second essay matches Zarathustra's Prologue suggests that the Overman is the person being discussed - someone whose values promote acting on his natural inclinations and oppose repressing them. Rather than being disunified because his instincts conflict with his bad conscience like the repressed Victorians of Nietzsche's time, the Overman's values would harmonize with his passions. Having these values would constitute turning the bad conscience around. Rather than being upset with himself about acting in a way driven by his instinctual passions and feeling proud about restraining them, he would feel proud of acting on them and upset with himself when he wasn't true to them. As a result, his spirit would be in harmony with his entrails, unifying his passions. That would make the Overman's character great in a way that Nietzsche thought he and his contemporaries couldn't be. 


\subsection{Nietzsche and Zarathustra}

I'll conclude by discussing a problem for subjectivism, and explaining how the passions of Nietzsche and Zarathustra solve it.

The problem is that Nietzsche, Zarathustra, and all who talk as they do may have little reason to care about the values they ascribe. Since all evaluative discourse concerns value for the agent, why would a speaker who isn't the agent care about this value? This reverses the classic problem for moral philosophy: Why should I do the good? Subjectivism solves that problem by grounding value in the agent's desires, giving every agent desire-based reasons to pursue value. But subjectivism faces the reverse problem - Why should I care about what's good for you? Why is Nietzsche so enthusiastic about others' character and actions?

Nietzsche's own passions explain this. He passionately admired people with strong and unified passions, and had contempt for others who lacked them. $\mathrm{He}$ strongly desired that people have strong desires that would constitute great character, make them produce great actions, and fill their lives with value. Subjectivism makes these people very valuable for him.

Writing through Zarathustra, Nietzsche can speak from the mouth of a purified version of himself with stronger passions for the Overman's existence, who can sincerely ascribe even more value to the Overman than he can. This is why Nietzsche hushes himself at the end of the second essay, reserving the right to speak of the Overman for someone strong enough. ${ }^{37}$ That's how I've treated Zarathustra throughout this essay: as the one who has the right passions to express Nietzsche's positive values with the fullest sincerity, force, and beauty, changing us into the people that Nietzsche wants us to be. ${ }^{38}$

\section{Notes}

1. Nietzsche (1954a), hereafter $Z$. Many good translations have recently appeared, including those of Del Caro, Martin, and Parkes. Kaufmann's translation may be most familiar to readers, helping them recognize quotations. 'Zarathustra' refers to the character, 'Zarathustra' to the book.

2. Schacht (1983) and Heidegger (1984) agree, opposed by Higgins (1987) and myself.

3. An attitude criticized by Loeb (2013).

4. Nietzsche (1969), hereafter EH: 'Among my writings my Zarathustra stands to my mind by itself. With that I have given mankind the greatest present that has ever been made to it so far. This book, with a voice bridging centuries, is not only the highest book there is, the book that is truly characterized by the air of the heights - the whole fact of man lies beneath it at a tremendous distance - it is also the deepest, born out of the innermost wealth of truth, an inexhaustible well to which no pail descends without coming up again filled with gold and goodness' (Preface 4).

5. See GM II:25, where Nietzsche silences himself to avoid saying what only Zarathustra has a right to say. Higgins notes Nietzsche's description of Zarathustra to Overbeck: 'It contains an image of myself in the sharpest focus, as I am, once I 
have thrown off my whole burde' (14). Salome (2001) similarly describes Zarathustra as the 'superior Nietzsche.'

6. My characterization of the metaethical positions follows Darwall, Gibbard, and Railton (1992), Miller (2003), and Shafer-Landau (2003).

7. Nietzsche (1997a), hereafter $D$.

8. Nietzsche (Nietzsche, 1966), hereafter $B G E$.

9. Nietzsche (1954b), hereafter TI.

10. For realist views, see Schacht (1983) and Wilcox (1974). For criticism, see Leiter (2000).

11. A subjectivist reading is defended in Langsam (1997). Robertson (2012) and Thomas (2012) are also helpful.

12. $\mathrm{x}$ is valuable for $\mathrm{Y}$ at the time when $\mathrm{Y}$ desires $\mathrm{x}$. Suppose Nietzsche desired in 1885 that Zarathustra be read in the twenty-first century. Here $\mathrm{x}=$ 'Zarathustra being read in the twenty-first century,' which had value for Nietzsche in 1885 , but not for little Nietzsche in 1845 or dead Nietzsche today. The relational nature of subjective value allows this. What if $Y$ desires $x$ at $t$, gets $x$ at $t+1$, and decides at $\mathrm{t}+2$ that $\mathrm{x}$ wasn't good at all? If $\mathrm{Y}$ lost the desire for $\mathrm{x}, \mathrm{x}$ went from being good for $\mathrm{Y}$ at $\mathrm{t}$ to not being good for $\mathrm{Y}$ at $\mathrm{t}+2$. Some cases supposed to be like this may instead involve failures of self-knowledge at $t$, with $\mathrm{Y}$ mistakenly selfascribing a desire for $\mathrm{x}$. In these cases, $\mathrm{x}$ never has value. Such mistakes may be common. As Ashwell (2013) notes, desires are harder to introspect than beliefs.

13. See Sinhababu (2009) and especially for the neuroscience, Schroeder (2004). We use 'desire' as the general term, subdivided into 'positive desire' and 'aversion.' I use 'passion' as the general term here to stay closer to Zarathustra. Passions are affectively charged and not merely motivational, as Katsafanas (2013) understands drives. While I read Nietzsche as reducing the subject to drives (see $B G E 12$ and $D$ 109), subjectivism doesn't require this commitment.

14. Helpfully noted in Reginster (2006).

15. Stevenson (1937) offers these interpretations, and advances semantic arguments of the kind that have made subjectivism unpopular in analytic moral philosophy.

16. Hume (1742) offers a subjectivism about aesthetics and taste resembling the subjectivism suggested here. This illuminates how Nietzsche's values can be seen as aesthetic. Harcourt (2011) discusses problems with other conceptions of Nietzsche's values as aesthetic.

17. Or so noncognitivists since Stevenson claim. See Gibbard (2003) and Schroeder (2008).

18. The images of scales and weighing fit the passage from 'On Those Who Are Sublime' above.

19. Featured as one of the 10 best papers of 2007 by Philosophers' Annual.

20. Nietzsche (1974), hereafter $G S$.

21. Clark and Dudrick (2007) offer a noncognitivist reading of this section. Hussain (2012) argues convincingly against it.

22. Nietzsche (1986), hereafter HH. Hussain accepts that GS 299 and 301 are compatible with subjectivism. So all the textual support Hussain adduces for error theory about even subjective value comes from $H H$. It's about Nietzsche's next book, Daybreak, that he would retrospectively say that his 'campaign against morality begins' ( $E H$ Dawn 1). Acknowledging subjective value springing from our passions and thinking morality prevents us from having the right kinds of passions might have inspired Nietzsche to actively campaign against morality.

23. Noted by Huddleston (2014).

24. '.. appetites for noble objects are laudable, those for base objects culpable' $1175 \mathrm{~b} 24-30$. 
25. Hurka lists many others who share this view, including Aristotle, Rashdall, Brentano, Moore, and Nozick. I ignore the recursive feature of his view, which may conflict with subjectivism.

26. It may seem circular for passions to make their objects valuable, and for this value to then constitute the passions as virtues. But if there are independent reasons for both steps, this circularity is not vicious, but virtuous. Zarathustra may allude to the circularity in 'On the Virtuous': 'The thirst of the ring lives in you: every ring strives and turns to reach itself again.'

27. $\mathrm{SV}$ is equal to $\Sigma(\mathrm{D}-\mathrm{A})^{2}$. Expanding it distinguishes the 'strength' and 'unity' components.

28. SV formally characterizes the importance of unified passions to Nietzsche, noted by Richardson (1996), Hurka (2007), and Risse (2007).

29. Katsafanas (2011) claims that Nietzsche counts a personality controlled by one strong drive as weak. But his only concrete textual example is Nietzsche (1997b) discussing Richard Wagner in the third essay of the Untimely Meditations (100-101), which suggests precisely the opposite! Nietzsche admired Wagner at that point, compares him to Goethe shortly afterward, and later praises 'natures of iron, such as Beethoven, Goethe, Schopenhauer and Wagner' (138).

30. EH repeatedly describes his experience in writing Zarathustra. See 3 of the Zarathustra section.

31. See again EH Preface 4, cited early in this essay, and also 6 of the Zarathustra section.

32. Aligning one's spirit with one's entrails seems similar to aligning one's 'agent values' with one's 'body values' as discussed in Richardson (2013). Von Tevenar (2013) discusses how this would overcome the ascetic ideal.

33. Also $D 481$.

34. Zarathustra criticizes the pure perceivers with similar imagery - 'your revolting worm has crawled into a god's mask.' As Higgins (1987) writes, he attacks 'the Kantian view that 'pure' judgments of the beautiful must be detached' (128).

35. Much recent scholarship underemphasizes the Overman. Tanner (1994) writes that after Zarathustra, 'the Übermensch is never heard of again' (70). But as Loeb (2005) insightfully argues, 'the Übermensch supersedes the entire analysis of the second essay of GM.' (72).

36. 'Let your will say: the Overman shall be the meaning of the earth ... Behold, I teach you the Overman: he is this sea; in him your great contempt can go under' ( $Z$ Prologue 3) and "Dead are all gods, now we want the Overman to live!' On that great noon, let this be our last will' ( $Z$ 'On the Gift-Giving Virtue').

37. Loeb (2005) notes that it's 'the only published place where Nietzsche explicitly if very briefly and cryptically - explains why he chose not to write TSZ in his own voice' (73).

38. This paper was improved by helpful discussion at Louisiana State University, the Society for Exact Philosophy, Sacramento State University, San Francisco State University, University of New Mexico, Utah State University, University of Kansas, University of Miami, University of South Florida, DePauw University, University of Portland, Boise State University, University of Queensland, La Trobe University, University of Tasmania, University of Western Australia, the Southampton Nietzsche's Postmoralism Conference, and Northern Illinois University. Two referees for this journal provided excellent comments, as did Mark Alfano, Kaity Creasy, Charlie Huenemann, Paul Loeb, and Simon Robertson. I'm grateful for conversations with my teachers Brian Leiter, Kathleen Higgins, Peter Berkowitz, Susan Hahn, and Beatrice Hanssen; and longtime friends Nick Stang, Matt Lawson, and Peter Bermel. 


\section{Notes on contributor}

Neil Sinhababu is an associate professor of Philosophy at the National University of Singapore. He received his $\mathrm{PhD}$ from the University of Texas at Austin and his BA from Harvard University, both in philosophy. His research interests began with Zarathustra and center around metaethics. His Humean Nature: How Desire Explains Action, Thought and Feeling is under contract with Oxford University Press. He has also written on epistemology, the philosophy of religion, and how to have romantic relationships with people in other possible worlds.

\section{References}

Aristotle. 1984. "Nicomachean Ethics." In The Complete Works of Aristotle. Translated by W. D. Ross and J. O. Urmson and edited by Jonathan Barnes. Princeton: Princeton University Press.

Ashwell, Lauren. 2013. "Deep, Dark ... or Transparent? Knowing Our Desires." Philosophical Studies 165 (1): 245-256.

Clark, Maudemarie, and David Dudrick. 2007. "Nietzsche and Moral Objectivity: The Development of Nietzsche's Metaethics." In Nietzsche and Morality, edited by Brian Leiter and Neil Sinhababu, 192-226. Oxford: Oxford University Press.

Darwall, Stephen, Allan Gibbard, and Peter Railton. 1992. "Toward Fin De Siecle Ethics: Some Trends." The Philosophical Review 101: 115-189.

Foenander, John. 2011. "A Reading of Nietzsche's Metaethics." MA thesis, National University of Singapore.

Gadamer, Hans-Georg. 1986. "Das Drama Zarathustras." Nietzsche-Studien 15: 1-15.

Gibbard, Allan. 2003. Thinking How to Live. Cambridge, MA: Harvard University Press.

Harcourt, Edward. 2011. "Nietzsche and the 'Aesthetics of Character'." In Nietzsche's on the Genealogy of Morality, edited by Simon May, 265-284. Cambridge: Cambridge University Press.

Heidegger, Martin. 1984. Nietzsche. Vol. 2 of The Eternal Recurrence of the Same. Translated by David Krell. San Francisco: Harper \& Row.

Higgins, Kathleen. 1987. Nietzsche's Zarathustra. Philadelphia, PA: Temple University Press.

Huddleston, Andrew. 2014. "Nietzsche's Meta-Axiology: Against the Sceptical Readings." British Journal for the History of Philosophy 22 (2): 322-342.

Hume, David. 1742. Of the Standard of Taste. http://www.econlib.org/library/LFBooks/ Hume/hmMPL23.html.

Hurka, Thomas. 2001. Virtue, vice, and value. Oxford: Oxford University Press.

Hurka, Thomas. 2007. "Nietzsche: Perfectionist" In Nietzsche and Morality, edited by Brian Leiter and Neil Sinhababu, 9-31. Oxford: Oxford University Press.

Hussain, Nadeem. 2007. "Valuing for Nietzsche's Free Spirits." In Nietzsche and Morality, edited by Brian Leiter and Neil Sinhababu, 157-191. Oxford: Oxford University Press.

Hussain, Nadeem. 2012. 'Nietzsche and Non-Cognitivism', Nietzsche, Naturalism, and Normativity. edited by Christopher Janaway and Simon Robertson, 111-132. Oxford: Oxford University Press.

Katsafanas, Paul. 2011. "The Concept of Unified Agency in Nietzsche, Plato, and Schiller." Journal of the History of Philosophy 49 (1): 87-113.

Katsafanas, Paul. 2013. "Nietzsche's Philosophical Psychology." In The Oxford Handbook of Nietzsche, edited by Ken Gemes and John Richardson, 727-755. Oxford: Oxford University Press. 
Langsam, Harold. 1997. "How to Combat Nihilism: Reflections on Nietzsche's Critique of Morality." History of Philosophy Quarterly 14: 235-253.

Leiter, Brian. 1997. "Nietzsche and the Morality Critics." Ethics 107 (2): 250-285.

Leiter, Brian. 2000. "Nietzsche's Metaethics: Against the Privilege Readings." European Journal of Philosophy 8 (3): 277-297.

Loeb, Paul. 2005. "Finding the Ubermensch in Nietzsche's Genealogy of Morality." Journal of Nietzsche Studies 30: 70-101.

Loeb, Paul. 2013. "Eternal Recurrence." In The Oxford Handbook of Nietzsche, edited by Ken Gemes and John Richardson, 645-674. Oxford: Oxford University Press.

Miller, Alexander. 2003. Introduction to Contemporary Metaethics. Cambridge: Polity Press.

Nietzsche, Friedrich. 1954a. Thus Spoke Zarathustra, in the Portable Nietzsche. Translated and edited by Walter Kaufmann, 103-439. New York: Penguin.

Nietzsche, Friedrich. 1954b. Twilight of the Idols, in the Portable Nietzsche. Translated and edited by Walter Kaufmann, 463-563. New York: Penguin.

Nietzsche, Friedrich. 1966. Beyond Good and Evil. Translated and edited by Walter Kaufmann. New York: Random House.

Nietzsche, Friedrich. 1969. Ecce Homo. Translated and edited by Walter Kaufmann. New York: Random House.

Nietzsche, Friedrich. 1974. The Gay Science. Translated and edited by Walter Kaufmann. New York: Random House.

Nietzsche, Friedrich. 1986. Human, All-Too-Human. Translated and edited by R. J. Hollingdale. Cambridge: Cambridge University Press.

Nietzsche, Friedrich. 1997a. Daybreak. Translated by R. J. Hollingdale, edited by Maudemarie Clark and Brian Leiter. Cambridge: Cambridge University Press.

Nietzsche, Friedrich. 1997b. Untimely Meditations. Translated by R. J. Hollingdale, edited by Daniel Breazeale. Cambridge: Cambridge University Press.

Poellner, Peter. 2007. "Affect Value, and Objectivity." In Nietzsche and Morality, edited by Brian Leiter and Neil Sinhababu, 227-261. Oxford: Oxford University Press.

Reginster, Bernard. 2006. The Affirmation of Life. Cambridge, MA: Harvard University Press.

Richardson, John. 1996. Nietzsche's System. Oxford: Oxford University Press.

Richardson, John. 2013. "Nietzsche on Life's Ends." In The Oxford Handbook of Nietzsche, edited by John Richardson and Ken Gemes, 756-784. Oxford: Oxford University Press.

Risse, Matthias. 2007. 'Nietzschean “Animal Psychology" versus Kantian Ethics', Nietzsche and Morality, edited by Brian Leiter and Neil Sinhababu, 57-82. Oxford: Oxford University Press.

Robertson, Simon. 2012. "The Scope Problem-Nietzsche, the Moral, Ethical, and Quasi-Aesthetic". In Nietzsche, Naturalism, and Normativity, edited by Christopher Janaway and Simon Robertson, 81-110. Oxford: Oxford University Press.

Salome, Lou. 2001. Nietzsche. Translated and edited by Siegfried Mandel. Urbana: University of Illinois Press.

Schacht, Richard. 1983. Nietzsche. London: Routledge \& Kegan Paul.

Schopenhauer, Arthur. 1969. The World as Will and Representation. Translated and edited by E. F. J. Payne. New York: Dover.

Schroeder, Timothy. 2004. Three Faces of Desire. Oxford: Oxford University Press.

Schroeder, Mark. 2008. "How Expressivists Can and Should Solve Their Problem with Negation." Noûs 42 (4): 573-599.

Shafer-Landau, Russ. 2003. Moral Realism. Oxford: Oxford University Press.

Shaw, Tamsin. 2007. Nietzsche's Political Skepticism. Princeton: Princeton University Press. 
Sinhababu, Neil. 2009. "The Humean Theory of Motivation Reformulated and Defended." Philosophical Review 118: 465-500.

Stevenson, Charles. 1937. "The Emotive Meaning of Ethical Terms." Mind 46: 14-31.

Tanner, Michael. 1994. Nietzsche. Oxford: Oxford University Press.

von Tevenar, Gudrun. 2013. "Zarathustra, That Malicious Dionysian." In The Oxford Handbook of Nietzsche, edited by Ken Gemes and John Richardson, 272-297. Oxford: Oxford University Press.

Thomas, Alan. 2012. "Nietzsche and Moral Fictionalism" in Nietzsche, Naturalism, and Normativity, edited by Christopher Janaway and Simon Robertson, 133-159. Oxford: Oxford University Press.

Wilcox, John. 1974. Truth and Value in Nietzsche: A Study of His Metaethics and Epistemology. Ann Arbor: University of Michigan Press. 